\title{
Remarriage in Finland
}

\author{
JARL LINDGREN
}

Senior Research Associate, Docent

The Population Research Institute

MAURI NIEMINEN

Head of Population Statistics

Central Statistical Office of Finland

\section{Introduction}

With industrialization and the accompanying urbanization great changes have occurred in the marriage and divorce pattern. An increasingly smaller portion of the population has remained unmarried. During the first half of the 1900s age at marriage declined. Since the beginning of the 1970s new features have become clearly evident. The age at marriage has risen, more for men than for women. Living in a consensual union has become more common among the young. There has been a strong increase in divorce. Among those who married in 1950 in Finland 18 percent were divorced 30 years later. The same level is being reached all the earlier by later marriage cohorts. Among those who married in 1970 the same proportion was already divorced 13 years later. There has been an especially strong increase in divorce during the first year of marriage.

A divorce does not demand, however, that the divorced parties remain single for the rest of their lives. For many a marital life style continues after a period of varying length, but with another partner, either in the form of a new marriage or a consensual union.

Remarriage in itself is not anything new. What is new is the background preceding a remarriage. Earlier in about all remarriages one, and often both partners came from a marriage which had dissolved because of the death of the spouse. Nowadays a remarriage is almost always preceded by a divorce. One hundred years ago, at the end of the 1880s, remarriage in Finland composed about 20 percent of all marriages being contracted (OSF, 1909). In the beginning of the 1980s, the proportion of remarriages was 15 percent (OSF, 1982-1986), of which only two percentage units represented marriages where one partner had been a widow or widower. Some of the divorced moved in together without getting married.

Gradually, as divorce has become more common, interest in the various aspects of remarriage has grown. Besides it being naturally worthwhile to be able to clarify to what extent remarriage occurs and when it occurs in regard to age and divorce, there is above all interest in the new marriage as a social institution, in many cases differing from the first marriage. In particular, a family with children, where one or both parents have been married previously, presents a markedly more many-sided and complicated network of relationships than the earlier family, while at the same time it is going through a developmental period different in many respects from what earlier, broken-up family went through. The new family is born out of a breaking away process from the earlier family situation and continues with a single-parent stage. In the new family the roles of family members are changed. Relationships increase 
and become more complex. Different members of the family can have different views of who belongs to the family, which in turn affects how they see their role and identity.

Internationally speaking, there is relatively little demographic information on remarriage, on the persons remarrying and their background. This is probably because, at least in part, the problems which are specific to remarried persons have not previously been considered notable or significant. In some countries smaller special studies concerning remarriage have been made, for example by examining their extent and related background factors. Usually, the official statistics record the most important data on remarriage like frequency, age, etc. Only a few countries seem to have more detailed statistics on remarriage.

Detailed data on remarriage in Finland is also lacking. Data on the length of the interval between divorce and remarriage is not recorded in the official statistics. Various background data concerning, for example, how long the previous marriage had lasted, the existence of children, how many children there are and how old, is not available. It is also unclear as to what extent the often expressed assumption holds true that single-parenthood lasts, for a relatively short period, that after divorce people quickly remarry or enter a consensual union. If this is the case, it would mean that children in many cases - except for a short transitional period - live in twoparent family, although one of the parents has been replaced by someone else.

\section{Objectives and method}

The aim of our presentation has been to clarify the structure of remarriage in Finland. Originally, we hoped to be able to make a study that would not only contain information on the structure and frequency of remarriage but also various types of background data, which can be considered to have an effect on the remarriage mechanism: for example, how long the previous marriage lasted or how many children the partners had when they remarried. Because of difficulties in obtaining the necessary material this has not been possible, however. Combining the various registers was also complicated and it did not seem worthwhile to do so for a small study like this alone. We have therefore had to be content with basing our work on information on remarriage concerning one single year, 1984 . We have mainly concentrated on calculating the interval between divorce and remarriage, the age at remarriage, and on estimating both the absolute number of remarried persons and their number in relation to the divorced, the married, and those living in the consensual union.

\section{The interval between remarriage and divorce}

Foreign studies seem to show that it is common to remarry during the very first year after divorce. The same tendency is apparent in our material concerning Finland. In 1984 the proportion of remarried was highest among those who had divorced the previous year. Among those who divorced between 1975 and 198414 percent of the women and 17 percent of the men divorced in 1983 (Table 1). The longer the interval between remarriage and divorce the smaller the proportion of divorced persons who remarried in 1984 . Only six percent of the men and slightly over seven percent of the women had divorced in 1975. Naturally remarriages occur also among those who divorced before the ten-year period we examined in the table. Their proportion is relatively small, however: for only 29 percent of all remarried women and 25 percent of all men was there an interval of ten to twenty years before they remarried. 
Among men who were divorced during the ten-year period studied, the median length of the time passing between divorce and remarriage was 3.7 years. ${ }^{1}$ Among women the interval was 3.2 years. Men remarry to a greater extent than women but somewhat later than women.

If the number of remarried persons is calculated in relation to the annual number of divorces, a picture arises somewhat similar to that in Table 2. The remarriage frequency is highest among men who divorced one year before they remarried, or 69 remarriages per one thousand divorces, for among those who had been divorced for ten years the number of remarriages had dropped to 23 per thousand and to 7 per thousand after 20 years (Figure 1). ${ }^{2}$ The remarriage frequency of women follows mainly that of men. The difference between men and women is greatest among those who have divorced relatively recently.

\section{The total remarriage frequency}

If one assumes that the remarriage pattern during the last few years has been the same as in 1984, which most probably is not entirely consistent with reality, it is possible to calculate how large a proportion of a divorced cohort will remarry. If one thus takes for a fact that each divorced cohort enters a new marriage according to the pattern presented in Figure 1, one reaches the conclusion that after ten years, among males 36 percent and among females 34 percent contract a new marriage. During the following ten years the proportion of remarriages increases but at a much slower rate. Twenty years after the divorce 43 percent of the men as well as women will be remarried (Figure 2).

As our material includes all remarriages, we have not been able to separate those who have been remarried before from those who are remarried for the first time. The proportion remarried for the second or more time is relatively small, though. In 1983 the proportion was 10.3 percent for men and 9.8 for women (OSF, 1985,

1 The median length of the interval between divorce and remarriage has been calculated for a fictitious cohort. The remarriage proportions on which the calculations are based are presented in Appendix Table 1 and the method of calculation of the remarriage proportions in Footnote 2.

${ }_{2}$ In the following figures and in the appendix tables exhibiting the remarriage pattern of divorce cohorts, the life table method has been used when calculating the cumulative rate of remarriage. The cumulative remarriage rate, ${ }_{i} q_{0}$, is $1-{ }_{j} p_{0}$ where ${ }_{j} p_{0}=p_{1} p_{2} p_{3} \ldots p_{j-1}$ is the cumulative proportion of divorced persons not yet remarried, $\mathrm{p}_{\mathrm{k}}$ stands for the yearly proportion of divorced persons not yet remarried, $p_{k}=1-r_{k}$ where $r_{k}$ represents the yearly remarried as a proportion of the yearly divorced when the proportion of earlier remarried has been substracted from the current number of divorced or $\mathrm{r}_{\mathrm{k}}=$ $\mathrm{d}_{\mathrm{k}} / \mathrm{l}_{\mathrm{k}}-\mathrm{l}_{\mathrm{k}}\left(\mathrm{d}_{0} / \mathrm{l}_{0}+\mathrm{d}_{1} / \mathrm{l}_{1}-\mathrm{l}_{1} \mathrm{~d}_{0} / \mathrm{l}_{0}+\mathrm{d}_{2} / \mathrm{l}_{2}-\mathrm{l}_{2} \mathrm{~d}_{1} / \mathrm{l}_{1}+\mathrm{d}_{3} / \mathrm{l}_{3} \mathrm{l}_{3} \mathrm{~d}_{2} / \mathrm{l}_{2}+\ldots+\mathrm{d}_{\mathrm{k}-1} / \mathrm{l}_{\mathrm{k}-1}-\mathrm{l}_{\mathrm{k}-1} \mathrm{~d}_{\mathrm{k}-2} / \mathrm{l}_{\mathrm{k}-2}\right)$ where $\mathrm{d}_{\mathrm{k}}$ is the number of yearly remarried and $l_{k}$ yearly divorced. Hence it is supposed that every yearly divorce cohort follows the same pattern as older cohorts, e.g. those divorced in 1980 are supposed to have remarried during the first year of divorce at the same rate as those divorced in 1984, during the second year as these divorced in 1983, etc. Clearly, the older the cohort the greater the probability that the pattern diverges from this assumption.

Mortality as a censoring event has not been taken into consideration in the calculations. As the largest part of the remarriages occur at a relatively young age, mortality is, of course, relatively low. If one starts with the assumption that the average age among those who entered a new marriage is 31 years (1984) and taking into consideration a period covering 20 years, mortality is so low that it can be disregarded. For men mortality can be calculated at around three percent, for women at only about one percent. Mortality increases with growing age. Hence it is possible that the figures remarriage frequency are somewhat too small among the oldest cohorts. 
$\mathrm{T}$ a b l e 1. Remarriage frequency and interval between divorce and remarriage in 1984

\begin{tabular}{|c|c|c|c|c|c|}
\hline $\begin{array}{l}\text { Interval } \\
\text { Year }\end{array}$ & $\begin{array}{c}\text { Men } \\
\%\end{array}$ & $\begin{array}{c}\text { Women } \\
\%\end{array}$ & $\begin{array}{l}\text { Interval } \\
\text { Year }\end{array}$ & $\begin{array}{c}\text { Men } \\
\%\end{array}$ & $\begin{array}{c}\text { Women } \\
\%\end{array}$ \\
\hline 1984 & 12.4 & 9.2 & $\begin{array}{ll}5 & 1979\end{array}$ & 9.8 & 8.0 \\
\hline 1983 & 16.7 & 14.5 & $\begin{array}{ll}6 & 1978\end{array}$ & 7.2 & 9.8 \\
\hline 1982 & 12.4 & 12.8 & $\begin{array}{ll}7 \quad 1977\end{array}$ & 6.9 & 7.7 \\
\hline 1981 & 11.3 & 10.8 & $\begin{array}{ll}8 & 1976\end{array}$ & 6.8 & 10.1 \\
\hline 1980 & 10.7 & 10.2 & $\begin{array}{ll}9 & 1975\end{array}$ & 5.6 & 7.0 \\
\hline
\end{tabular}

Source: Appendix table 1.

F i g u r e 1. Remarriages in 1984 per 1000 divorces in 1965-1984.

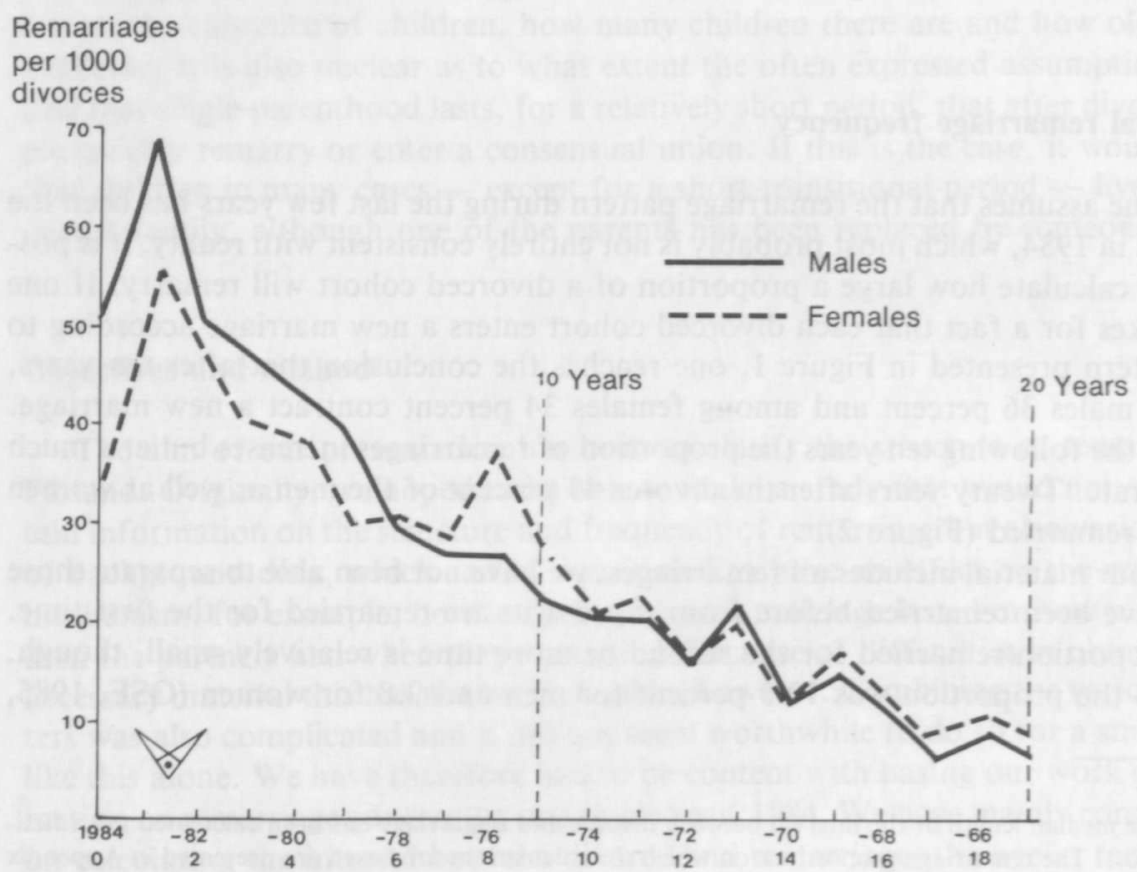

Source: Appendix table 1.

$\mathrm{T}$ a b l e 2. Age at remarriage in 1984 .

$\begin{array}{lrr}\text { Age } & \text { Men } & \text { Women } \\ -19 & - & 0.1 \\ 20-24 & 10.9 & 5.2 \\ 25-29 & 10.1 & 19.1 \\ 30-34 & 23.4 & 25.8 \\ 35-39 & 26.0 & 23.7 \\ 40-44 & 15.6 & 11.7 \\ 45-49 & 10.3 & 6.6 \\ 50-54 & 6.4 & 3.9 \\ 55-59 & 3.9 & 2.1 \\ 60- & 3.3 & 1.88 \\ & 99.9 & 100.0 \\ & \mathrm{M}=38.0 & \mathrm{M} .=35.0 \\ & \mathrm{X}=39.4 & \mathrm{X}=34.2 \\ & \mathrm{~N}=3919 & \mathrm{~N}=3812\end{array}$

The table is based on data from OSF VI A, I, 150. Population 1984. 
F i g u r e 2. Remarriage frequency for a divorce cohort whose remarriage pattern is the same as for the remarried of 1984 .

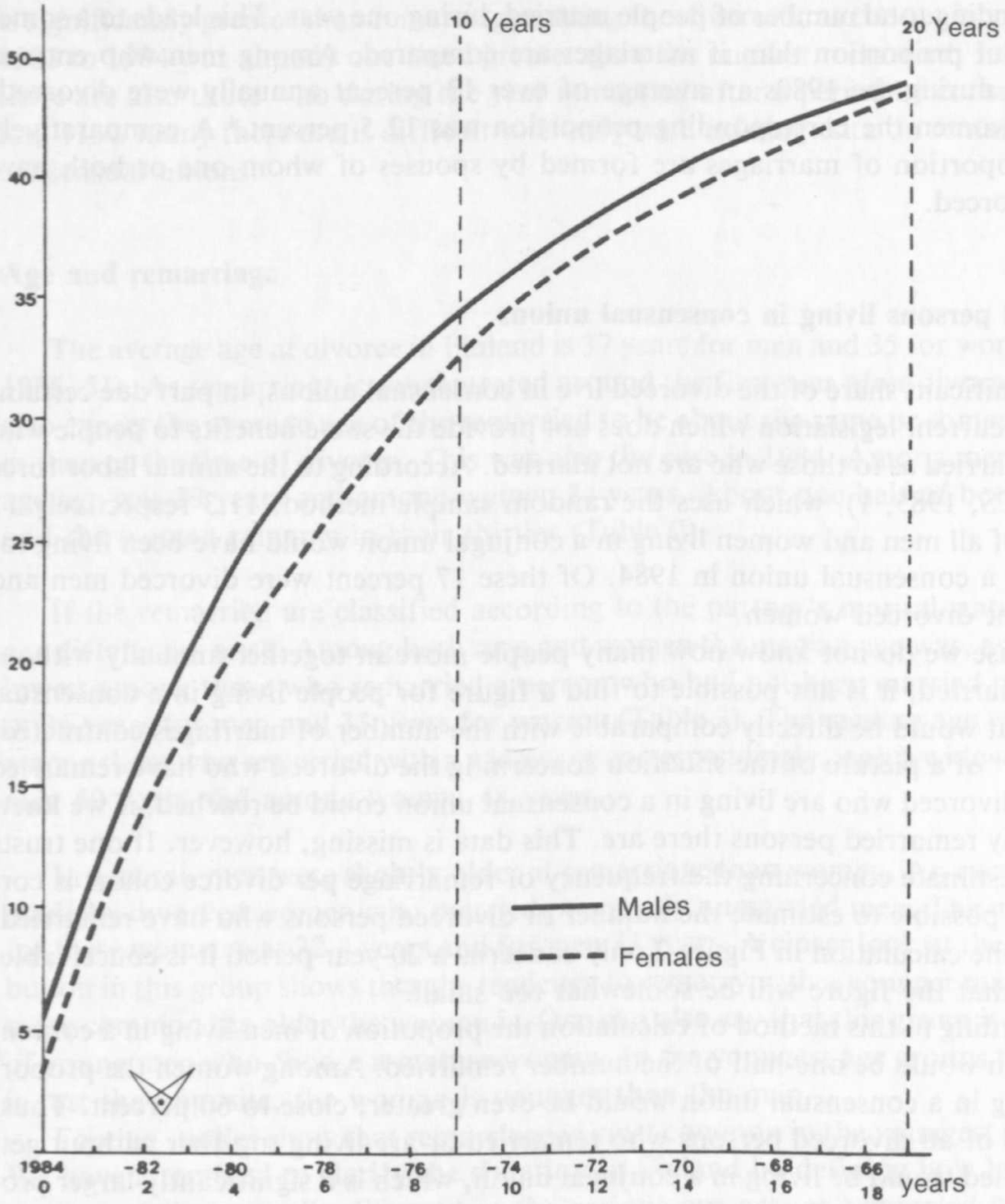

Source: Appendix table 1.

46-47). Figures 1 and 2 therefore represent mainly the remarriage frequency of persons who have been divorced once.

In the 1980s the proportion of marriages where one or both spouses has been divorced has gone up on the average to 20 percent of all marriages contracted yearly. ${ }^{3}$

${ }^{3}$ Proportion of marriages where one or both spouses have been previously married of all marriages contracted

$\begin{array}{cc}\text { Year } & \% \\ 1980 & 23.7 \\ 1981 & 19.9 \\ 1982 & 19.7 \\ 1983 & 20.9 \\ 1984 & 20.5\end{array}$


A picture of the remarriage frequency's size on an individual basis is provided by a direct comparison between the number of remarried men and women and the corresponding total number of people married during one year. This leads to a somewhat lower proportion than if marriages are compared. Among men who entered marriage during the 1980 s an average of over 13 percent annually were divorced. Among women the corresponding proportion was 12.5 percent. ${ }^{4} \mathrm{~A}$ comparatively small proportion of marriages are formed by spouses of whom one or both have been divorced.

\section{Divorced persons living in consensual unions}

A significant share of the divorced live in consensual unions, in part due certainly to our current legislation which does not provide the same benefits to people who have remarried as to those who are not married. According to the annual labor force survey (CS, 1985, 1), which uses the random sample method, 11.3 respectively 11 percent of all men and women living in a conjugal union would have been living together in a consensual union in 1984. Of these 17 percent were divorced men and 21 percent divorced women.

Because we do not know how many people move in together annually without getting married, it is not possible to find a figure for people living in a consensual union that would be directly comparable with the number of marriages contracted. Some sort of a picture of the situation concerning the divorced who have remarried and the divorced who are living in a consensual union could be reached, if we knew how many remarried persons there are. This data is missing, however. If one trusts that the estimate concerning the frequency of remarriage per divorce cohort is correct, it is possible to estimate the number of divorced persons who have remarried. Because the calculation in Figure 2 only concerns a 20 -year period it is conceivable, though, that the figure will be somewhat too small. ${ }^{5}$

According to this method of calculation the propotion of men living in a consensual union would be one-half of the number remarried. Among women the proportion living in a consensual union would be even greater, close to 60 percent. Thus, one-third of all divorced persons who remarried or are living together without getting married would be living in a conjugal union, which is a significantly larger proportion than that concerning the entire population.

The question remains to be answered of how large a proportion of those who are divorced annually move in together without getting married. By comparing the statistics for 1983 with those 1984 we can, of course, find the net increase or de-

${ }^{4}$ Proportion of remarried persons of all married persons, according to sex

$\begin{array}{ccc}\text { Year } & \begin{array}{c}\text { Men } \\ \%\end{array} & \begin{array}{c}\text { Women } \\ \%\end{array} \\ 1980 & 12.4 & 11.3 \\ 1981 & 13.1 & 12.5 \\ 1982 & 12.9 & 12.2 \\ 1983 & 13.9 & 13.1 \\ 1984 & 13.7 & 13.3\end{array}$

5 In the statistics for 1984 partners in a consensual union who were separated but not divorced were grouped together with the divorced. In the previous year's report, where separated and divorced are held apart, among men 13 percent of the whole group were separated. Among women the corresponding proportion was four percent. Here it has been assumed that the situation was the same in 1984 as in 1983. 
crease, but the statistics in their current form do not answer the question. It can be assumed, of course, that the formation of consensual unions by divorced persons is significantly greater than remarriage among the divorced, as the net increase from 1983 to 1984 was already one-third greater than the number remarried. In addition, there are also those who during the year remarried after a period of consensual union. How many there are is difficult to clarify with existing data on remarriage and consensual unions.

\section{Age and remarriage}

The average age at divorce in Finland is 37 years for men and 35 for women (OSF, $1985,51)$. As remarriage is concentrated around the first year after divorce, one can also expect the average age of the remarried to be about the same or somewhat higher than at the time of divorce. This was also the case in 1984. Among men the average age was 39 years and among women 34 years. About one-half of both the men and the women remarry in their thirties (Table 2).

If the remarried are classified according to the partner's marital status, certain age differences arise. Among both men and women the median age was, as expected, lowest among those who remarried a person who had not been married previously, or 36 years for men and 33 years for women (Table 3). The median age was highest among those who remarried with a widow, or correspondingly, with a widower, among men 50 years and among women 48 years.

In general, men were slightly older at remarriage than women. An exception was made by divorced women who married previously unmarried men. The median age for these women was 32.4 years and for men 31 years. A closer look at the age distribution in this group shows that the tendency to remarry with a younger man becomes more common the older the woman is. One can also say that this group is composed of young men who choose a mature woman. In the youngest age groups the pattern is just the opposite, the woman is younger than the man.

Foreign studies show that remarriage is most common in the youngest age group. We have attempted to clarify the situation in Finland by defining how large a proportion of the annually divorced in the various age groups remarried in 1984 .

Because we have not extended our examination further than to those who divorced in 1971, our figures probably underestimate the situation, especially perhaps in the

$\mathrm{T}$ a b l e 3. Median age among the remarried in 1984 according to the spouse's marital status.

$\begin{array}{llcl}\text { Men remarried to } & \text { Man's age } & \text { Woman's age } & \\ \begin{array}{l}\text { - unmarried } \\ \text { - divorced }\end{array} & 35.8 & 28.8 & \mathrm{~N}=2045 \\ \text { - widow } & 40.2 & 37.3 & \mathrm{~N}=1739 \\ \text { Woman remarried to } & 50.4 & 48.1 & \mathrm{~N}=138 \\ \text { - unmarried } & & & \\ \text { - divorced } & 31.0 & 32.4 & \mathrm{~N}=1893 \\ \text { - widower } & 40.2 & 37.3 & \mathrm{~N}=1736 \\ \end{array}$

See footnote in table 2. 
44

F i g u re 3. Remarriage according to age at divorce and age at remarriage

Remarriages

per 1000

divorces
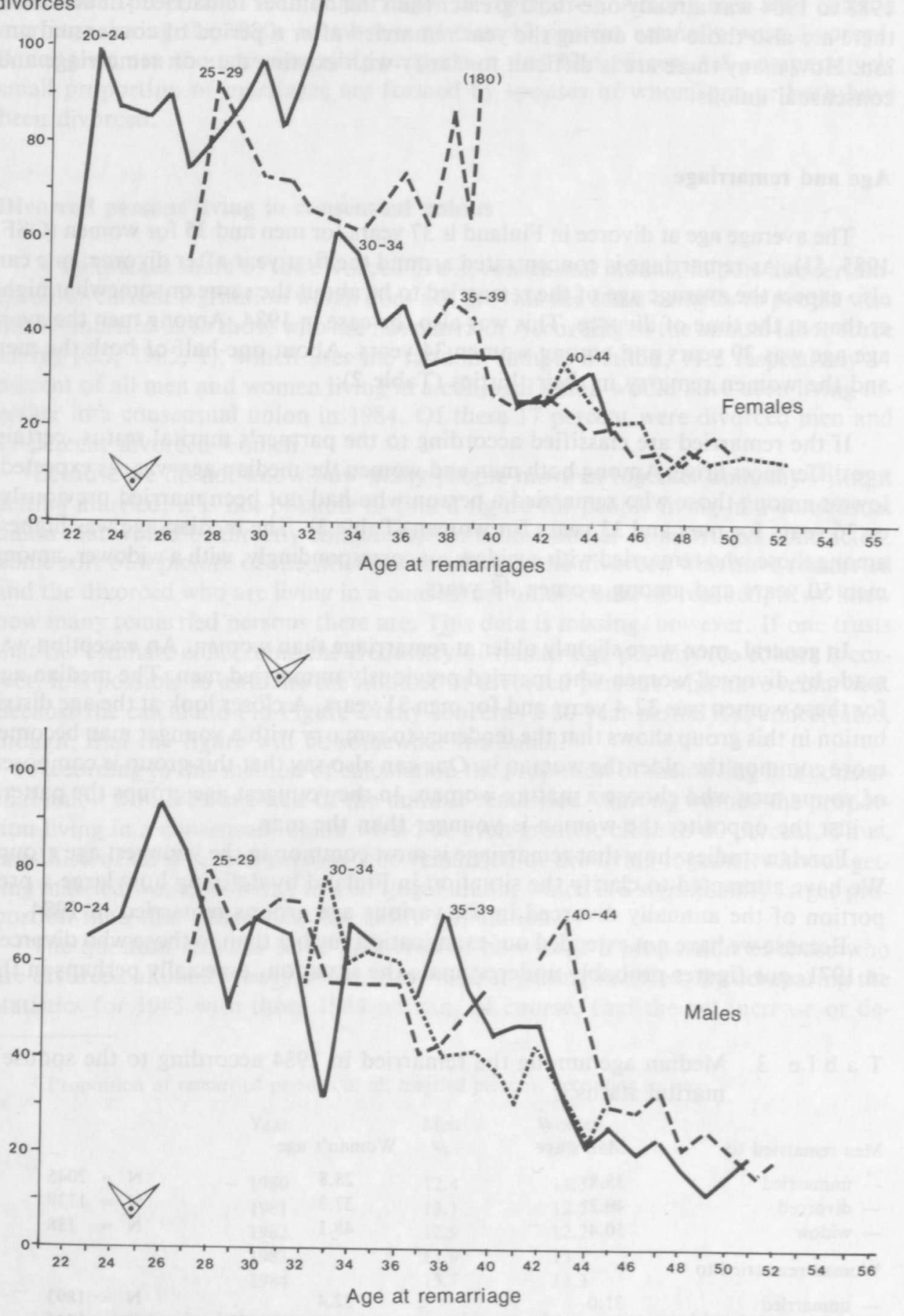

Source: Appendix table 2. The age group (age at divorce) has been placed along the age-axis on the middle to the age group. The age group's distribution is generally skewed, however. 
youngest age groups. We also have not been able to include groups older than the $40-44$-year-olds. The extent of our study thus describes the distribution of remarriage during the last 14 years with focus on the interval between divorce and remarriage and age at divorce. Contrarily, one can, if assuming that the remarriage pattern for all cohorts is the same that it has been for the last few decades, project the pattern on various age cohorts and thus obtain their remarriage probabilities. The estimated values are naturally more trustworthy the shorter the interval between divorce and remarriage.

Our study indicates that remarriage frequency is highest among the youngest age groups, those in their twenties. Just after the divorce many a new marriage is contracted. After that a decreasing tendency is observable. Towards the end of the period studied remarriage seems to show a strong increasing tendency. However, one has to be careful in interpreting the results which the curves exhibit. The small size of the material makes it susceptible to random variations as the great yearly differences in remarriage frequency show, at least at the end of the period.

In the later age groups remarrying decreases explicitly with age, but also according to the time passed since divorce. In these age groups remarriage is obviously highest just after the divorce. Among 40-44-year-old women only three percent remarry the second year after divorce compared with ten percent among the twenty-year-olds.

The difference between men and women is evident. Among men the remarriage frequency is almost the same in all age groups just after the divorce. After that remarrying tends to go down. The decreasing tendency is most marked in the later age groups. Again the random variations seem to be most obvious in the curve representing the youngest age group.

A better picture of the total remarriage frequency is given by adding together the yearly frequencies. Calculated on the basis of $1984 \mathrm{~s}$ remarriages and the interval between divorce and remarriage a total of about 50 percent of men aged 20-29 years should remarry (Table 4). Among 20-24-year-old women the total figure rises even higher or to over 64 percent, then to drop gradually with age. In the oldest age group, among the 40-44-year-olds, it was only 18 percent among women and 32 percent among men.

It is clear that these figures cannot unrestrictedly be used for making an estimate of years to come since we are, as it seems, going through a period of transition with continuously increasing consensual unions.

$\mathrm{Ta} \mathrm{b} \mathrm{l} \mathrm{e} \mathrm{4.} \mathrm{The} \mathrm{total} \mathrm{remarriage} \mathrm{frequency} \mathrm{per} \mathrm{five-year-age} \mathrm{group} \mathrm{calculated} \mathrm{for}$ a period of 16 years after divorce.

$\begin{array}{lcc}\text { Age } & \begin{array}{c}\text { Men } \\ \%\end{array} & \begin{array}{c}\text { Women } \\ \%\end{array} \\ 20-24 & 52.7 & 64.2 \\ 25-29 & 50.9 & 54.6 \\ 30-34 & 44.0 & 35.2 \\ 35-39 & 36.3 & 26.1 \\ 40-44 & 31.8 & 18.4\end{array}$




\section{Conclusions}

The increased number of divorces has led to an increased number of remarriages. Family building at remarriage seems in many respects to bear structural features different from those in the more common first marriage. Norms and relationship patterns are different. Because up till now remarriage has formed a relatively small part of all marriages, official statistics have not been concerned in greater detail with data related to remarriage.

The aim of our study was a basic examination of the structure of remarriage. A lack of resources has forced us, though, to lower our aims. Our small material has not enabled us to create a full picture of remarriage in Finland. Many questions remain unanswered.

Despite this we have been able to fill in many details in the previously very incomplete picture of remarriage. We have found that remarriage is very common. We found that as a total somewhat more than an eighth of all men and women who married in the 1980 s were remarrying. Of all divorced persons about 55 percent remarried. There are naturally differences between the remarriage frequencies of the various age groups. The largest frequencies are found in the youngest age groups. Among 20-year-olds one-half of the men and close to two-thirds of the women remarry.

I addition to remarriage, consensual unions have become very common among divorced persons. On the basis of our calculations the number of divorced persons living in consensual unions should rise to about one-half the number of remarried. It remains to be clarified how many divorced persons move in together yearly without marrying.

A central question in our study was to gain an understanding of how long people were divorced before a new marriage was contracted. Compared with information from other countries it appears that in Finland people remarry rathet quickly after their divorce. Among those who entered a new marriage within a 10 -year period after the divorce, one-half of the men and over 40 percent of the women had remarried during the first three years after their divorce.

Our interest in clarifying the length of the interval between divorce and remarriage was dictated mainly by a wish to gain an understanding of to what extent remarriage occurs in families with children. In this way, we could see how long singleparenthood lasts in families with children, to what extent single-parenthood is only a transitional period of short nature. For technical reasons we were not able to separate families with children from those who had no children, so that this important question still remains to be answered.

As a whole, it appears that remarriage in Finland seems to be just as common as in Central Europe, but more common than in other Scandinavian countries, except perhaps for Norway. We are living in a transitional period, however, where living together in consensual unions is becoming all the more common. The data for the last few years on consensual unions points firmly in this direction.

\section{References}

CSO (Central Statistical Office of Finland). (1985). Avoliitossa elävät 1984 (Cohabitation 1984). Tilastotiedotus, Väestö, VÄ 1985: 7. Helsinki, Finland.

Festy, Patrick. (1985). Le divorce, la séparation judiciaire et le remariage. Évolution recent dans les éstats membres du Conseil de l'Europe. Etudes démographiques, No. 17. Strasbourg : Conseil de l'Europe.

OSF (Official Statistics of Finland). (1909). Éléments démographiques principaux de la Finlande pour les années 1750-1890. VI, 41, III, p. 79. Helsinki: Central Statistical Office of Finland.

OSF (Official Statistics of Finland). (1982-1986). Structure of population and vital statistics. Whole country and provinces. VI A, I, 145-150, 1980-1984. Helsinki: Central Statistical Office of Finland. 
A p p e n d ix T a b le 1. Yearly numbers of divorces 1965-1984, number of remarriages in 1984 by year of divorce, and remarriages as a proportion of annual divorces.

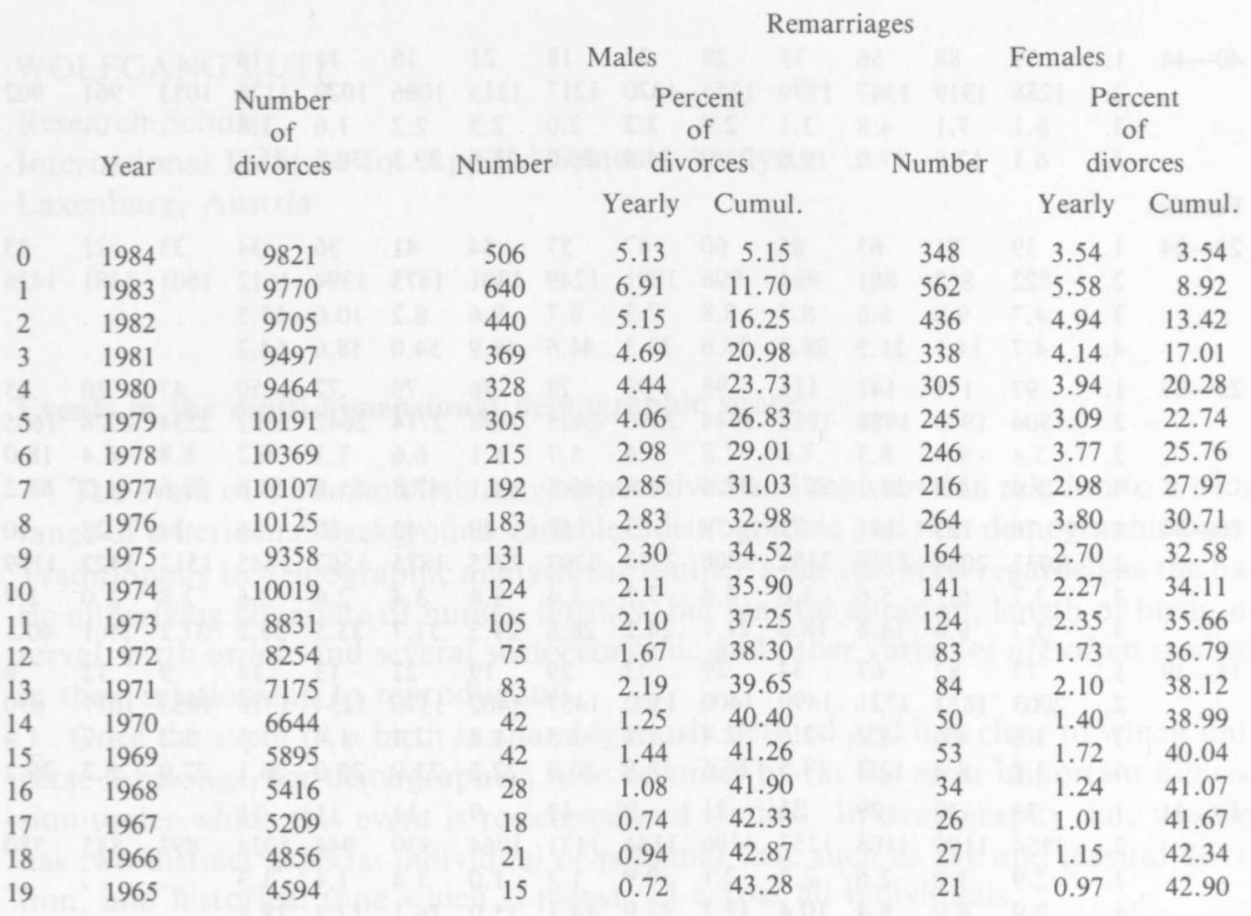

A p p e n d ix T a b l e 2. Remarriages in 1984 by age groups and years of divorce, and as a proportion of annual divorces

Males

Year of divorce

\begin{tabular}{|c|c|c|c|c|c|c|c|c|c|c|c|c|c|c|c|}
\hline \multirow[t]{2}{*}{ Year } & & 0 & 1 & 2 & 3 & 4 & 5 & 6 & 7 & 8 & 9 & 10 & 11 & 12 & 13 \\
\hline & & 1984 & 1983 & 1982 & 1981 & 1980 & 1979 & 1978 & 1977 & 1976 & 1975 & 1974 & 1973 & 1972 & 1971 \\
\hline \multicolumn{16}{|l|}{ Age } \\
\hline \multirow[t]{4}{*}{$20-24$} & 1. & 18 & 22 & 22 & 34 & 27 & 20 & 16 & 22 & 22 & 13 & 9 & 17 & 11 & \\
\hline & 2. & 341 & 349 & 357 & 452 & 451 & 458 & 550 & 658 & 742 & 697 & 847 & 823 & 738 & 859 \\
\hline & 3. & & 6.6 & 7.0 & 9.3 & 8.3 & 6.9 & 5.1 & 6.9 & 6.6 & 4.9 & 3.2 & 6.9 & 6.5 & 14.2 \\
\hline & 4. & 5.3 & 11.6 & 17.7 & 25.4 & 31.6 & 31.3 & 39.6 & 43.7 & 47.5 & 50.1 & 51.7 & 55.0 & 57.9 & 58.7 \\
\hline \multirow[t]{4}{*}{$25-29$} & 1. & 85 & 114 & 91 & 90 & 89 & 92 & 72 & 63 & 64 & 59 & 36 & 30 & 28 & 19 \\
\hline & 2. & 1421 & 1506 & 1575 & 1636 & 1678 & 1910 & 2215 & 2208 & 2501 & 2513 & 2551 & 2198 & 2041 & 1589 \\
\hline & 3. & 6.0 & 8.0 & 6.7 & 6.9 & 7.3 & 7.4 & 5.6 & 5.5 & 5.5 & 5.7 & 4.0 & 4.4 & 5.1 & .2 \\
\hline & 4. & 6.0 & 13.5 & 19.3 & 24.9 & 30.4 & 35.6 & 39.2 & 42.6 & 45.7 & 48.8 & 50.9 & 53.0 & 55.4 & 57.9 \\
\hline \multirow[t]{4}{*}{$30-34$} & 1. & 118 & 164 & 131 & 115 & 104 & 86 & 63 & 56 & 46 & 28 & 38 & 24 & 14 & 17 \\
\hline & 2. & 2106 & 2168 & 2523 & 2285 & 2306 & 2574 & 2429 & 2266 & 2161 & 1786 & 1896 & 1632 & 1541 & 1285 \\
\hline & 3. & 5.6 & 8.0 & 6.0 & 6.3 & 6.1 & 4.9 & 4.1 & 4.2 & 3.9 & 3.1 & 4.2 & 3.4 & 2.2 & .5 \\
\hline & 4. & 5.6 & 13.1 & 18.4 & 23.5 & 28.1 & 31.7 & 34.5 & 37.2 & 39.7 & 41.5 & 44.0 & 45.9 & 47.1 & 48.9 \\
\hline \multirow[t]{4}{*}{$35-39$} & 1. & 115 & 137 & 92 & 61 & 57 & 56 & 34 & 23 & 25 & 17 & 19 & 12 & 7 & 11 \\
\hline & 2. & 2150 & 2023 & 1924 & 1641 & 1551 & 1631 & 1687 & 1617 & 1537 & 1423 & 1407 & 1223 & 1147 & 98 \\
\hline & 3. & 5.3 & 7.2 & 5.5 & 4.5 & 4.7 & 4.7 & 3.0 & 2.2 & 2.6 & 2.0 & 2.3 & 1.7 & 1.1 & \\
\hline & 4. & 5.3 & 12.1 & 170 & 20.7 & 24.5 & 28.0 & 30.2 & 31.7 & 33.5 & 34.8 & 36.3 & 37.4 & 38.1 & 9. \\
\hline
\end{tabular}


Males

Year of divorce

Year $\begin{array}{llllllllllllll}0 & 1 & 2 & 3 & 4 & 5 & 6 & 7 & 8 & 9 & 10 & 11 & 12 & 13\end{array}$

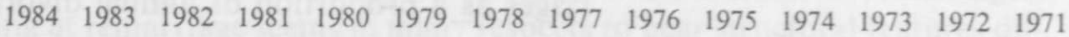

$\begin{array}{rrrrrrrrrrrrrrrr}40-44 & 1 . & 79 & 88 & 56 & 33 & 29 & 32 & 18 & 21 & 16 & 11 & 14 & \ldots & \ldots & \ldots\end{array}$

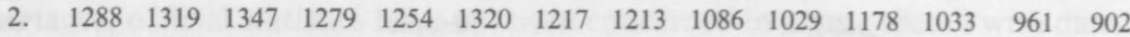

$\begin{array}{lllllllllllllll}3 . & 6.1 & 7.1 & 4.8 & 3.1 & 2.9 & 3.2 & 2.0 & 2.5 & 2.2 & 1.6 & 1.8 & \ldots & \ldots & .\end{array}$ 4. $\quad \begin{array}{lllllllllllllll}6.1 & 12.8 & 17.0 & 19.6 & 22.0 & 24.4 & 26.0 & 27.8 & 29.3 & 30.5 & 31.8 & \ldots & \ldots & \ldots\end{array}$

Females

$\begin{array}{llllllllllllllll}20-24 & 1 . & 39 & 81 & 65 & 65 & 60 & 47 & 57 & 54 & 41 & 36 & 34 & 33 & 21 & 35\end{array}$

2. $\quad \begin{array}{llllllllllllll}822 & 862 & 881 & 991 & 996 & 1091 & 1249 & 1301 & 1473 & 1394 & 1612 & 1501 & 1381 & 1426\end{array}$

3. $\quad \begin{array}{lllllllllllllll}4.7 & 9.8 & 8.6 & 8.5 & 8.8 & 7.3 & 8.7 & 9.6 & 8.2 & 10.0 & 13.5 & \ldots & \ldots & \ldots\end{array}$

$\begin{array}{lllllllllllllll}4 . & 4.7 & 14.1 & 21.5 & 28.2 & 34.6 & 39.3 & 44.6 & 49.9 & 54.0 & 58.6 & 64.2 & \ldots & \ldots & .\end{array}$

$\begin{array}{llllllllllllllll}25-29 & 1 . & 97 & 171 & 141 & 111 & 98 & 93 & 78 & 76 & 79 & 72 & 50 & 47 & 20 & 25\end{array}$

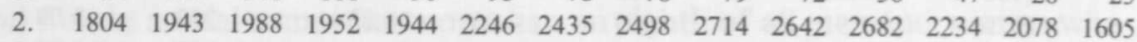

3. $\quad \begin{array}{rlllllllllllll}5.4 & 9.3 & 8.3 & 7.4 & 7.2 & 6.6 & 5.7 & 6.1 & 6.6 & 7.3 & 6.2 & 8.8 & 6.4 & 18.0\end{array}$

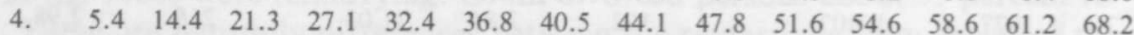

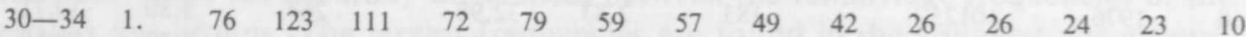

2. $\quad \begin{array}{llllllllllllll}2032 & 2084 & 2220 & 2152 & 2206 & 2382 & 2297 & 2075 & 1875 & 1567 & 1645 & 1517 & 1422 & 1119\end{array}$

$\begin{array}{llllllllllllllll}3 . & 3.7 & 6.1 & 5.6 & 4.0 & 4.4 & 3.2 & 3.4 & 3.4 & 3.4 & 2.6 & 2.6 & 2.8 & 3.0 & 1.7\end{array}$

4. $\quad \begin{array}{llllllllllllll}3.7 & 9.6 & 14.6 & 18.0 & 21.7 & 24.2 & 26.8 & 29.3 & 31.7 & 33.5 & 35.2 & 37.2 & 39.1 & 40.1\end{array}$

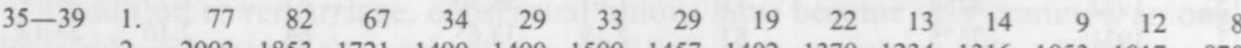

2. $\begin{array}{llllllllllllll}2003 & 1853 & 1721 & 1490 & 1400 & 1500 & 1457 & 1402 & 1370 & 1234 & 1316 & 1053 & 1017 & 870\end{array}$

$\begin{array}{lllllllllllllll}3 . & 3.8 & 4.6 & 4.2 & 2.6 & 2.4 & 2.7 & 2.5 & 1.8 & 2.1 & 1.4 & 1.5 & 1.2 & 1.7 & 1.4\end{array}$

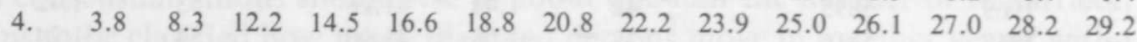

$\begin{array}{llllllllllllllll}40-44 & 1 . & 33 & 37 & 29 & 23 & 21 & 9 & 13 & 9 & 11 & 11 & 11 & \ldots & \ldots & \ldots\end{array}$

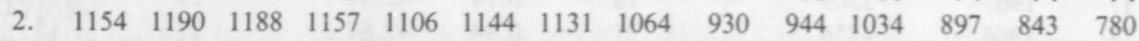

$\begin{array}{llllllllllllllllll}3 . & 2.9 & 3.2 & 2.6 & 2.2 & 2.1 & 0.9 & 1.3 & 1.0 & 1.4 & 1.4 & 1.3 & \ldots & \ldots & \ldots\end{array}$

$\begin{array}{lllllllllllllllll}\text { 4. } & 2.9 & 6.0 & 8.4 & 10.4 & 12.3 & 12.9 & 14.1 & 15.0 & 16.1 & 17.3 & 18.4 & \ldots & \ldots & \ldots\end{array}$

1. Remarriages by year of divorces

2. Number of divorces

3. Remarriages as a proportion of annual divorces

4. Cumulative proportion of remarriages (for calculation see p. 39) 